\title{
Reoperation for Coarctation of the Aorta
}

ROBERT H. BEEKMAN, MD

ALBERT P. ROCCHINI, MD

DOUGLAS M. BEHRENDT, MD

AMNON ROSENTHAL, MD, FACC

Ann Arbor, Michigan
Between 1957 and 1980 reoperation for coarctation of the aorta was performed in 21 patients at one institution for an overall incidence rate of 7.9 percent. The incidence rate of reoperation was 38 percent for patients younger than age 3 years and 1.5 percent for patients 3 years or older at initial repair. Before reoperation 14 of the 21 patients were symptomatic, 19 had systolic hypertension of the upper limbs and 20 had a documented coarctation pressure gradient at rest (mean $42.4 \mathrm{~mm} \mathrm{Hg}$ ). Surgical techniques used at reoperation were patch aortoplasty in 12 patients, graft interposition in 4, end to end anastomosis in 3 and end to side left subclavian to descending aorta bypass graft in 2 . There was one surgical death. The 20 survivors have been followed up a mean of 4.3 years. There has been significant symptomatic improvement $(p<0.001)$. Upper limb hypertension has also lessened significantly $(p<0.001)$ after reoperation; 15 patients are no longer hypertensive and 3 have a lesser degree of hypertension. The coarctation pressure gradient at rest has significantly decreased ( $p<0.001$ ); 13 patients have no residual gradient and 7 have a mild gradient of $20 \mathrm{~mm} \mathrm{Hg}$ or less. Graded treadmill exercise testing performed in five patients after reoperation documented upper limb hypertension in four and a marked increase in coarctation gradient with exercise in three.

In conclusion, the incidence of reoperation is significantly increased in patients who are younger than age 3 years at initial coarctation repair. Reoperation is a safe and effective procedure. It has a low mortality rate (4.8 percent), relieves symptoms and decreases hypertension and the coarctation pressure gradient. Patch aortoplasty appears to be the operative procedure of choice. Moderate to severe hemodynamic abnormalities may persist during exercise after reoperation for coarctation of the aorta.

The long-term prognosis after repair of coarctation of the aorta is not entirely benign. Associated structural cardiovascular lesions such as mitral or aortic valve disease, ventricular septal defect and cerebrovascular malformations are responsible for considerable postoperative morbidity and mortality. ${ }^{1-6}$ There may also be persistent postoperative hypertension that is often related to residual or recurrent narrowing at the site of coarctation repair. ${ }^{7-13}$ Many patients will require a second operation to relieve this stenosis. ${ }^{13-16}$ Nevertheless, there are few reported data concerning the indications, risks involved and long-term results to be expected after reoperation for coarctation. In this retrospective study we attempt to address these questions by reviewing our experience with 21 patients who underwent reoperation for coarctation of the aorta.

\section{Methods}

Study patients: The hospital records of all patients operated on for coarctation of the aorta at this institution between 1957 and 1980 were reviewed. Twenty-one patients were identified who underwent reoperation for coarctation. Hospital records, operative reports, catheterization data and angiograms were thoroughly reviewed, specific attention being paid to associated cardiovascular lesions, the nature of the initial surgical procedure, the indications for and nature of reoperation when necessary, operative morbidity and mortality, postoperative upper limb blood pressure, pressure gradient across the coarctation and clinical 
status. When available, pressure gradients determined at cardiac catheterization were used in preference to auscultatory measurements. For simplicity, a coarctation pressure gradient was considered to be $0 \mathrm{~mm} \mathrm{Hg}$ when the systolic pressure distal to the coarctation equaled or exceeded that proximal to the coarctation.

Statistical significance was assessed with the $t$ test for paired observations and with the chi-square test. Values are expressed as mean \pm standard error of the mean.

\section{Results}

\section{Primary Repair}

Of the 21 patients who required reoperation $17 \mathrm{had}$ undergone initial repair at this institution between 1957 and 1973 , and 4 were initially operated on elsewhere. Details of the initial operative procedure are outlined in Table I. The age at initial repair ranged from 3 weeks to 24 years (mean $3.8 \pm 1.3$ ). Fifteen patients $(71$ percent) were 2 years old or younger and 10 (48 percent) were less than 1 year old at initial repair. All patients had a discrete coarctation of the thoracic aorta. A variety of associated cardiovascular lesions were present, including patent ductus arteriosus (eight patients), mitral valve disease (six patients), tubular hypoplasia of the aortic arch (five patients) and ventricular septal defect (three patients).

Initial operative procedure: Primary excision with end to end anastomosis was the initial operative procedure in 20 patients. Interrupted sutures were utilized around the anterior half to two thirds of the anastomosis in all 18 patients in whose chart suture technique was recorded. Bleeding from the anastomosis necessitated oversewing of the suture line in two patients (Cases 9 and 14). A 24 year old man (Case 21), operated on elsewhere, had an end to side left subclavian to descending aorta bypass graft as his initial surgical procedure.

Time of recurrence of coarctation: Data concerning age at onset of the residual or recurrent coarctation pressure gradient were not available for the four patients whose initial repair occurred at another hospital. Of the 17 patients whose coarctation was repaired at this institution 15 had simultaneous upper and lower limb pressures recorded during the immediate postoperative period (Table I). Residual pressure gradients were detected consistently in six patients, all but one being $20 \mathrm{~mm} \mathrm{Hg}$ or greater. In the remaining 11 patients pressure gradients at rest were first detected 0.2 to 6.2 (mean 2.8 \pm 0.6 ) years after initial repair of coarctation. All patients were seen in the follow-up period, and upper and lower limb blood pressures were measured every 6 to 12 months. Once detected, the pressure gradient at rest increased gradually over time in the majority of patients (Fig. 1, A and C). Three patients (Cases 5,8 and 12) had a rapid onset of the maximal coarctation gradient. These gradients developed over several months and changed minimally during the subsequent follow-up period (Fig. 1B).

\section{Reoperation}

Incidence: From 1957 to 1973, the years during which the patients requiring reoperation underwent initial repair of coarctation, a total of 239 patients survived the initial operation at this institution (Table II). Nineteen (7.9 percent) of these required reoperation.

TABLE I

Nature of Initial Coarctation Repair and Subsequent Course in 21 Patients Who Required Reoperation

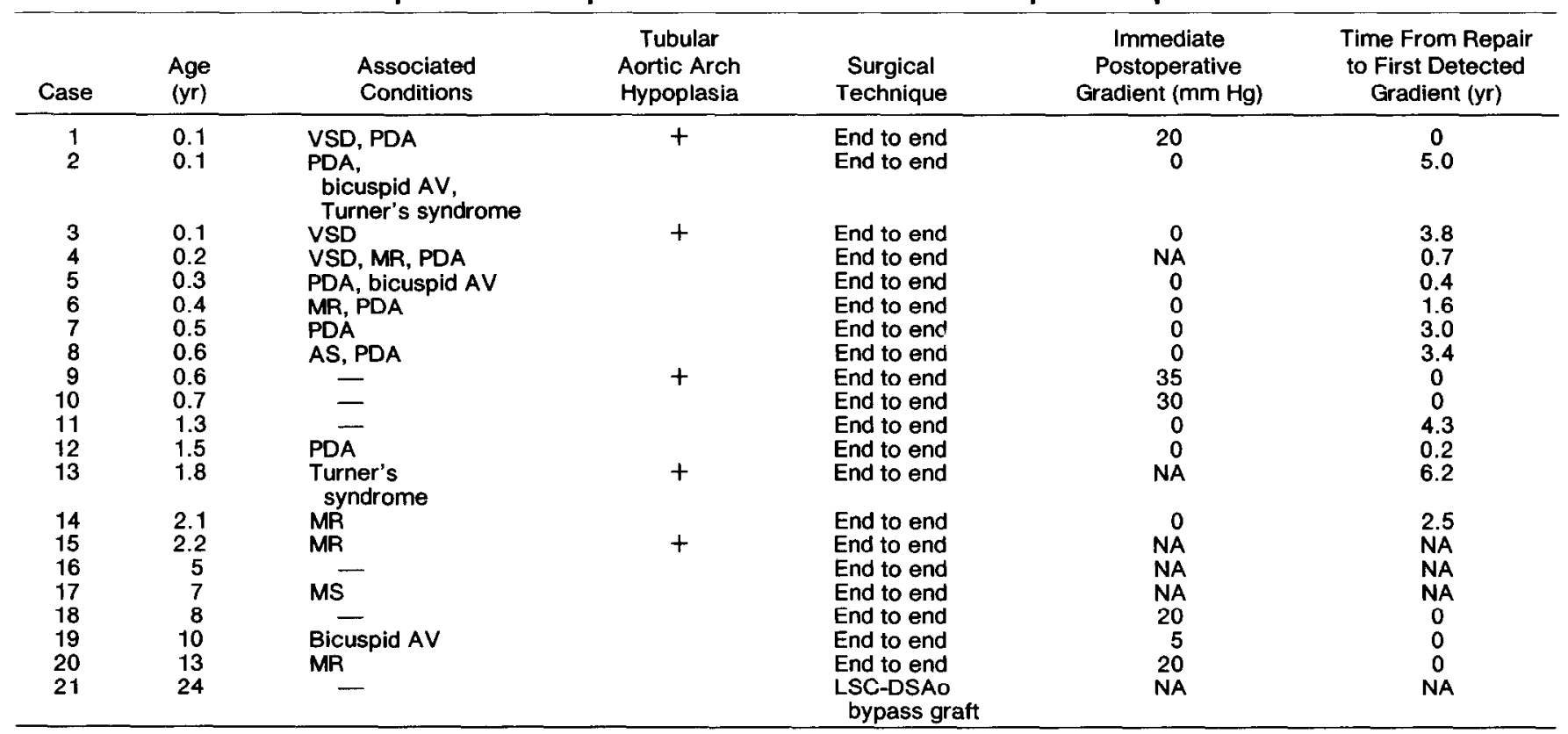

$A S=$ aortic stenosis; $A V=$ aortic valve; $L S C-D S A o=$ left subclavian to descending aorta; MR = mitral regurgitation; MS = mitral stenosis; $\mathrm{NA}=$ data not available; $\mathrm{PDA}=$ patent ductus arteriosus; $\mathrm{VSD}=$ ventricular septal defect. 


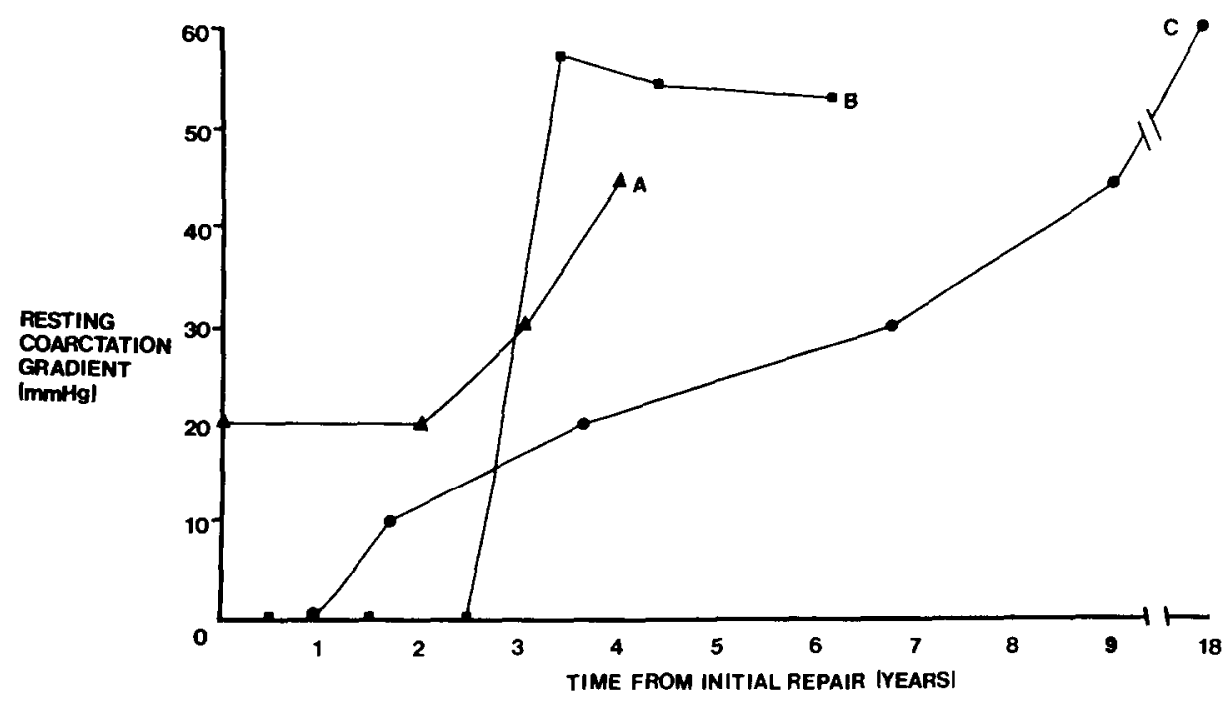

FIGURE 1. Time course of development of coarctation in three patients. A, Case 18. Residual gradient that gradually increased with time. B, Case 8. Rapid onset of maximal gradient. C, Case 6. Recurrent gradient that gradually increased with time.
This group includes the 17 patients previously described plus 1 patient with initial repair at this hospital who underwent reoperation at another institution and 1 patient scheduled for reoperation in the near future. Of the 42 children who were less than age 3 years at initial repair, 16 (38 percent) required reoperation. When the 0 to 12 month and 1 to 2 year age groups are evaluated separately, the incidence of reoperation is nearly identical ( 38 and 40 percent, respectively). Only 3 of 197 patients who were 3 years or older at initial repair required reoperation, a significantly smaller incidence than that observed in the younger groups (chi-square $=58, \mathrm{p}<0.001$ ).

Clinical features at time of reoperation (Table III): The mean age at reoperation was $11.2 \pm 1.4$ years; the youngest patient was 23 months and the oldest 30 years. The interval from initial repair to reoperation averaged $7.4 \pm 1.0$ years (range 21 months to 17.5 years). Symptoms occurred in 14 of the 21 patients. Lower limb claudication was the most common symptom, occurring in nine patients. Three complained of frequent severe headaches and the two oldest patients, each with severe hypertension, experienced dyspnea on exertion. Upper limb (right arm) systolic hypertension, defined as greater than the 95 th percentile for age and sex, ${ }^{17}$ was

\section{TABLE II}

Incidence of Reoperation for Coarctation of the Aorta

\begin{tabular}{cccc}
\hline $\begin{array}{c}\text { Age at Initial } \\
\text { CoA Repair }\end{array}$ & $\begin{array}{c}\text { Survivors } \\
\text { of } \\
\text { Initial Repair } \\
(1957-1973)(\mathbf{n})\end{array}$ & $\begin{array}{c}\text { Patients } \\
\text { Requiring } \\
\text { Reoperation (n) }\end{array}$ & $\begin{array}{c}\text { Follow-Up } \\
(\mathbf{y r})\end{array}$ \\
\hline $\begin{array}{c}\text { 0-3 yr } \\
0-11 \mathrm{mo}\end{array}$ & 42 & $16(38 \%)$ & 10.8 \\
$\begin{array}{c}12-35 \mathrm{mo} \\
\geq 3 \mathrm{yr}\end{array}$ & 10 & $\begin{array}{c}12(38 \%) \\
4(40 \%)\end{array}$ & $\begin{array}{r}9.5 \\
12.0\end{array}$ \\
Total & 197 & $3(1.5 \%)$ & 6.5 \\
\hline
\end{tabular}

$\mathrm{CoA}=$ coarctation of aorta present in 19 patients and diastolic hypertension was also present in 12 .

A systolic pressure gradient at rest across the site of coarctation repair was documented in 20 of the 21 patients. This information was unavailable for one patient whose lower limb pressure could not be measured. In 13 patients the pressure gradient was measured using direct pullback from the ascending to the descending aorta during cardiac catheterization; in the remaining 7 patients the gradient was documented on two or more occasions by simultaneous auscultation of right arm and leg pressures. The systolic pressure gradient at rest averaged $42.4 \pm 2.1 \mathrm{~mm} \mathrm{Hg}$ (range 25 to 60 ). There was no correlation between the coarctation gradient and patient age, upper limb hypertension or clinical status. All patients had greatly diminished or absent lower limb pulses.

Aortography was performed in 17 patients before reoperation. A discrete narrowing at the site of previous repair of coarctation was evident in each case (Fig. 2). At its narrowest point the aortic internal diameter averaged $42 \pm 2$ percent (range 23 to 59 ) of its diameter at the level of the diaphragm. Aortic cross-sectional area was reduced to $18 \pm 2$ percent (range 5 to 34 ) of its area at the diaphragm. No correlation was found between the reduction in aortic internal diameter or cross-sectional area and the coarctation gradient at rest, upper limb hypertension or clinical status. The aortic diameter at the isthmus was equal to its diameter at the diaphragm in all five patients who had tubular arch hypoplasia in infancy.

Surgical techniques and complications: The four surgical techniques used at reoperation were patch aortoplasty in 12 patients, graft interposition in 4 , end to end anastomosis in 3 and end to side left subclavian to descending aorta bypass graft in 2 . Nine of the patients required left heart bypass. In the majority of patients dense adhesions were observed in the area of the coarctation. Operative morbidity was minimal with patch aortoplasty, a chylothorax that required 11 days of chest tube drainage developing in one patient. Sig- 
TABLE III

Pertinent Clinical Data Immediately Before and After Reoperation for Coarctation in 21 Patients

\begin{tabular}{|c|c|c|c|c|c|c|c|c|c|c|}
\hline \multirow[b]{2}{*}{ Case } & \multirow[b]{2}{*}{$\begin{array}{c}\text { Age } \\
(y r)\end{array}$} & \multirow[b]{2}{*}{ Symptoms } & \multirow[b]{2}{*}{$\begin{array}{l}\text { Right Arm } \\
\text { Pressure } \\
\text { at Rest } \\
\text { (mm Hg) }\end{array}$} & \multirow[b]{2}{*}{$\begin{array}{l}\text { Coarctation } \\
\text { Gradient } \\
\text { at Rest } \\
(\mathrm{mm} \mathrm{Hg})\end{array}$} & \multirow[b]{2}{*}{$\begin{array}{l}\text { Surgical } \\
\text { Procedure }\end{array}$} & \multirow[b]{2}{*}{$\begin{array}{c}\text { Immediate } \\
\text { Postoperative } \\
\text { Gradient } \\
\text { (mm Hg) }\end{array}$} & \multicolumn{4}{|c|}{ Follow-Up } \\
\hline & & & & & & & $\begin{array}{l}\text { Length } \\
\text { (yr) }\end{array}$ & $\begin{array}{l}\text { Right Arm } \\
\text { Pressure } \\
\text { at Rest } \\
\text { (mm Hg) }\end{array}$ & $\begin{array}{c}\text { Coarctation } \\
\text { Gradient } \\
\text { at Rest } \\
(\mathrm{mm} \mathrm{Hg})\end{array}$ & Symptoms \\
\hline $\begin{array}{l}1 \\
2 \\
3 \\
4 \\
5 \\
6\end{array}$ & $\begin{array}{l}6.0 \\
13 \\
6.8 \\
1.9 \\
13.5 \\
18\end{array}$ & $\begin{array}{l}\text { Claudication } \\
\text { Claudication } \\
- \\
\text { Dyspnea }\end{array}$ & $\begin{array}{l}155 / 70 \\
196 / 98 \\
120 / 82 \\
170 / 100 \\
174 / 112 \\
190 / 95\end{array}$ & $\begin{array}{l}53^{*} \\
30^{*} \\
30^{*} \\
50^{*} \\
40^{*} \\
60\end{array}$ & $\begin{array}{l}\text { Patch } \\
\text { Patch } \\
\text { Patch } \\
\text { Patch } \\
\text { Patch } \\
\text { LSC-DSAo } \\
\text { bypass graft }\end{array}$ & $\begin{array}{r}0 \\
0 \\
8 \\
33 \\
0 \\
0\end{array}$ & $\begin{array}{r}9 \\
0.5 \\
0.2 \\
5 \\
3 \\
0.7\end{array}$ & $\begin{array}{l}110 / 70 \\
155 / 82 \\
100 / 70 \\
106 / 60 \\
130 / 80 \\
138 / 64\end{array}$ & $\begin{array}{c}0 \\
0 * \\
8 \\
15^{*} \\
0 \\
0\end{array}$ & $\begin{array}{l}\text { None } \\
\text { None } \\
\text { None } \\
\text { None } \\
\text { None } \\
\text { None }\end{array}$ \\
\hline $\begin{array}{l}7 \\
8 \\
9\end{array}$ & $\begin{array}{r}8.5 \\
6.8 \\
17\end{array}$ & $\begin{array}{l}\text { Claudication } \\
\text { Headaches } \\
-\end{array}$ & $\begin{array}{l}114 / 74 \\
134 / 72 \\
150 / 80\end{array}$ & $\begin{array}{l}44 \\
54 \\
47^{*}\end{array}$ & $\begin{array}{l}\text { End to end } \\
\text { End to end } \\
\text { Interposition } \\
\text { graft }\end{array}$ & $\begin{array}{l}0 \\
0 \\
0\end{array}$ & $\begin{array}{l}6.5 \\
6.5 \\
3.5\end{array}$ & $\begin{array}{c}114 / 52 \\
115 / 78 \\
160 / 100\end{array}$ & $\begin{array}{r}14 \\
0 \\
10\end{array}$ & $\begin{array}{l}\text { None } \\
\text { None } \\
\text { None }\end{array}$ \\
\hline $\begin{array}{l}10 \\
11 \\
12 \\
13\end{array}$ & $\begin{array}{c}3.5 \\
11 \\
4.5 \\
9\end{array}$ & $\begin{array}{l}\text { Claudication } \\
\text { Claudication } \\
\text { Claudication } \\
\text { Headaches }\end{array}$ & $\begin{array}{l}120 / 80 \\
125 / 65 \\
145 / 70 \\
125 / 90\end{array}$ & $\begin{array}{l}50 \\
34 \\
37^{*} \\
25\end{array}$ & $\begin{array}{l}\text { Patch } \\
\text { End to end } \\
\text { Patch } \\
\text { Interposition } \\
\text { graft }\end{array}$ & $\begin{array}{r}0 \\
0 \\
0 \\
20\end{array}$ & $\begin{array}{r}5.5 \\
7 \\
4.5 \\
7\end{array}$ & $\begin{array}{r}95 / 65 \\
100 / 70 \\
110 / 70 \\
150 / 95\end{array}$ & $\begin{array}{c}0 \\
0 \\
0 \\
15^{*}\end{array}$ & $\begin{array}{l}\text { None } \\
\text { None } \\
\text { None } \\
\text { None }\end{array}$ \\
\hline $\begin{array}{l}14 \\
15 \\
16 \\
17\end{array}$ & $\begin{array}{r}7 \\
10 \\
16 \\
9\end{array}$ & $\begin{array}{l}\text { - } \\
\text { Claudication } \\
\text { Headaches }\end{array}$ & $\begin{array}{l}150 / 90 \\
178 / 98 \\
150 / 80 \\
150 / 75\end{array}$ & $\begin{array}{l}50^{*} \\
40^{*} \\
31^{*} \\
42^{*}\end{array}$ & $\begin{array}{l}\text { Patch } \\
\text { Patch } \\
\text { Patch } \\
\text { LSC-DSAo } \\
\text { bypass graft }\end{array}$ & $\begin{array}{r}18 \\
0 \\
0 \\
0\end{array}$ & $\begin{array}{r}7 \\
1 \\
0.2 \\
0.9\end{array}$ & $\begin{array}{l}140 / 72 \\
150 / 65 \\
120 / 78 \\
120 / 65\end{array}$ & $\begin{array}{c}10 \\
0 \\
0 \\
0\end{array}$ & $\begin{array}{l}\text { None } \\
\text { None } \\
\text { None } \\
\text { Late } \\
\text { death }\end{array}$ \\
\hline $\begin{array}{l}18 \\
19\end{array}$ & $\begin{array}{l}12 \\
14.5\end{array}$ & $\begin{array}{l}\text { Claudication } \\
\text { Claudication }\end{array}$ & $\begin{array}{l}135 / 90 \\
142 / 95\end{array}$ & $\begin{array}{l}45 \\
50\end{array}$ & $\begin{array}{l}\text { Patch } \\
\text { Interposition } \\
\text { graft }\end{array}$ & - & 10 & $\begin{array}{c}148 / 70 \\
-\end{array}$ & 20 & $\begin{array}{l}\text { None } \\
\text { Surgical } \\
\text { death }\end{array}$ \\
\hline 20 & 16.5 & - & $146 / 84$ & $36^{*}$ & Patch & 0 & 5 & $135 / 90$ & 0 & $\begin{array}{l}\text { Late } \\
\text { death }\end{array}$ \\
\hline 21 & 30 & $\begin{array}{l}\text { Dyspnea, chest } \\
\text { pain }\end{array}$ & $200 / 130$ & NA & $\begin{array}{l}\text { Interposition } \\
\text { graft }\end{array}$ & 0 & 2.5 & $130 / 95$ & 0 & Hoarse \\
\hline
\end{tabular}

* Gradient measured at cardiac catheterization.

Abbreviations as in Table I.

nificant intraoperative complications occurred in two of the four patients undergoing graft interposition. The only surgical death occurred in a patient (Case 19) who experienced an aortic rupture, had a severe coagulopathy and died in the operating room. The oldest pa-

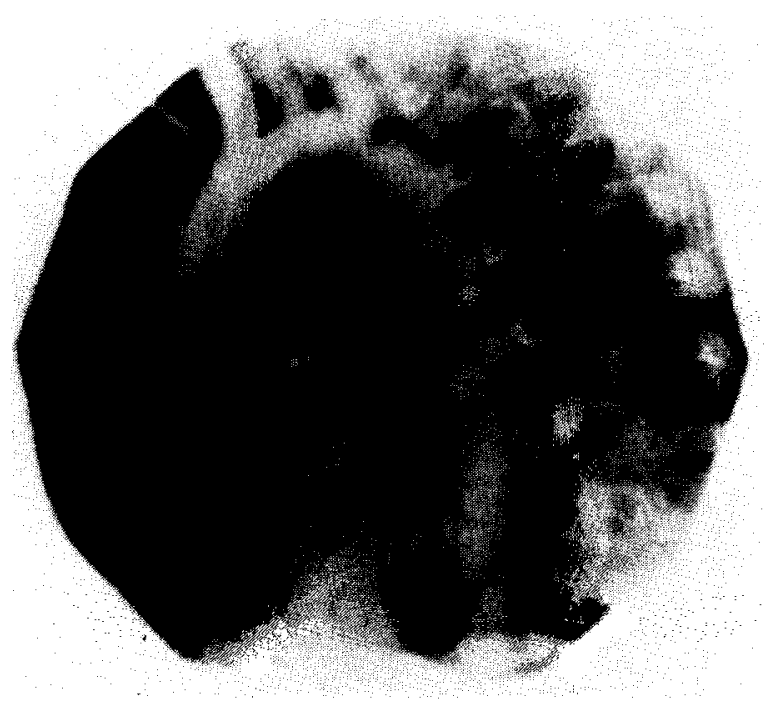

FIGURE 2. Patient 8 . Aortogram of patient with recurrent coarctation before reoperation. A discrete narrowing is evident distal to the left subclavian artery. tient (Case 21) had a friable calcified aorta that required graft insertion. During the procedure a pulmonary arterial tear occurred, requiring 12 liters of blood replacement before the hemorrhage was controlled. This patient has postoperative recurrent laryngeal nerve damage. The three patients who had coarctation excision and end to end anastomosis and the two who had a left subclavian arterial to descending aorta bypass graft had no intraoperative complications.

Simultaneous upper and lower limb pressures were recorded during the immediate postoperative period in all 20 survivors of reoperation. Fifteen patients had no residual pressure gradient. Five patients had a gradient averaging $22 \pm 4 \mathrm{~mm} \mathrm{Hg}$, recorded across the site of coarctation repair. Four of the five had undergone patch aortoplasty and one a graft interposition.

\section{Follow-Up Study}

The 20 survivors of reoperation have been followed up a mean of $4.3 \pm 0.7$ years (Table III). There has been significant symptomatic improvement (chi-square $=$ $9.3, p<0.001$ ). Seventeen patients are entirely asymptomatic and no patient has symptoms referable to coarctation. One patient is hoarse because of recurrent laryngeal nerve damage. There have been two late deaths (Cases 17 and 20) related to severe aortic and mitral valve disease; however, neither patient had a residual coarctation pressure gradient after reoperation. 


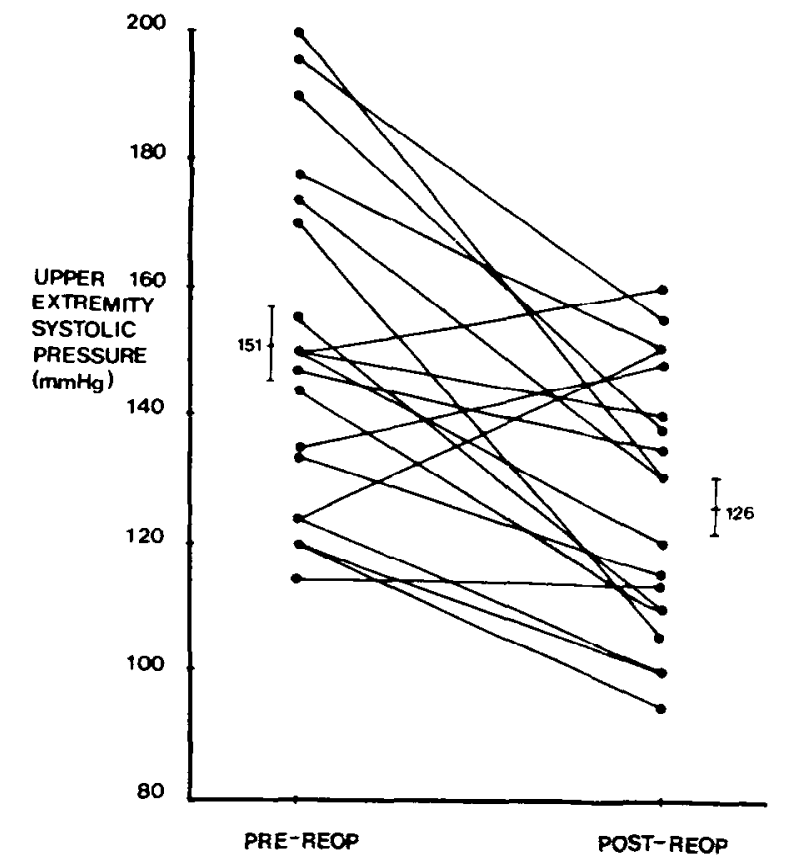

FIGURE 3. Upper limb systolic pressure at rest before and after reoperation (REOP) for coarctation $(p<0.001)$.

Hypertension (Fig. 3): There has been a significant reduction in upper limb hypertension after reoperation ( $p<0.001)$. Mean systolic pressure for the group decreased from $151 \pm 6$ to $126 \pm 5 \mathrm{~mm} \mathrm{Hg}$. Only two patients have elevated diastolic pressure after reoperation. Fifteen patients are no longer hypertensive and three have a lesser degree of hypertension. Two patients, each with a residual coarctation gradient, have had no lessening of their hypertension. Only one patient is taking antihypertensive medication. It should be noted that two of three survivors of graft interposition have remained hypertensive.

Coarctation pressure gradient: Figure 4 illustrates the significant effect of reoperation on the coarctation pressure gradient at rest $(\mathrm{p}<0.001)$. In every instance this gradient has decreased. Thirteen patients have no gradient at rest after reoperation, and seven have a pressure gradient of $20 \mathrm{~mm} \mathrm{Hg}$ or less. In five patients the residual gradient was first detected in the immediate postoperative period and in none has it progressed. In two patients (Cases 7 and 9) a mild pressure gradient appeared 3.5 and 6.5 years, respectively, after reoperation.

Effect of exercise: Five patients underwent graded treadmill exercise testing after reoperation (Table IV). Significant upper limb hypertension (greater than 200 $\mathrm{mm} \mathrm{Hg}$ ) developed in four patients. Patient 6, whose reoperation consisted of a left subclavian to descending aorta bypass graft, had striking hypertension and a coarctation gradient of $134 \mathrm{~mm} \mathrm{Hg}$ with exercise. $\mathrm{Pa}$ tients 2 and 4 , both of whom had undergone patch aortoplasty, demonstrated only modest increases in coarctation pressure gradient with exercise (32 and 15 $\mathrm{mm} \mathrm{Hg}$, respectively).

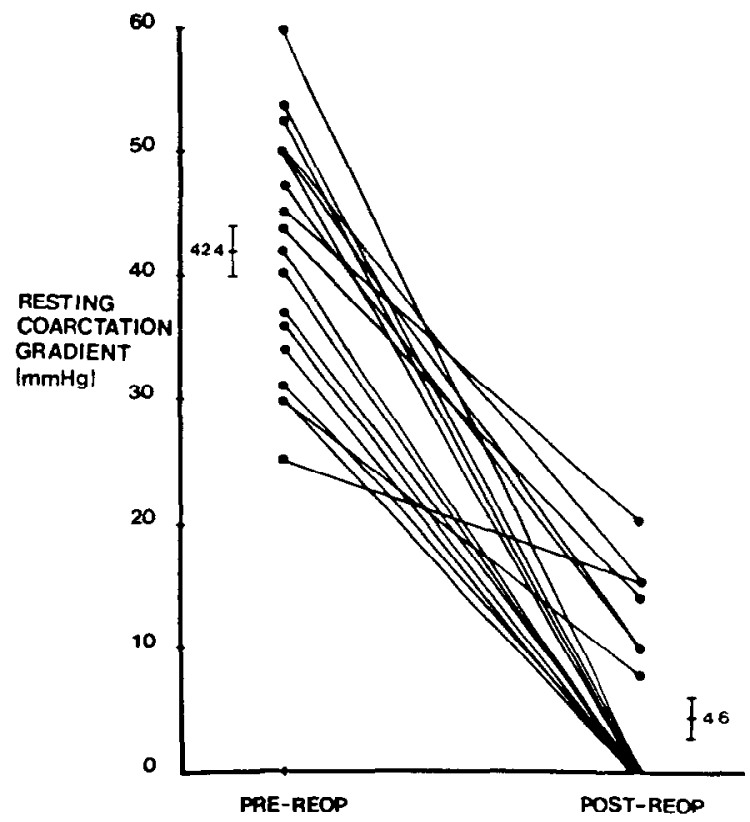

FIGURE 4. Coarctation pressure gradient at rest before and after reoperation (REOP) for coarctation $(p<0.001)$.

\section{Discussion}

The long-term results after coarctation repair in infancy are often unsatisfactory. Residual or recurrent coarctation has frequently been observed, ${ }^{4-13}$ the reported incidence rate ranging from 16 to 54 percent. Our study documented a 38 percent incidence rate of reoperation among children who were less than age 3 years at initial repair of coarctation. In contrast, the incidence rate of reoperation was only 1.5 percent for patients 3 years or older at initial repair (Table II).

Causes of residual coarctation: The factors responsible for an unsuccessful initial repair of coarctation are not entirely clear. A residual coarctation was undoubtedly present in the six patients who had a significant pressure gradient measured in the immediate postoperative period. Inadequate surgical repair appears to be the cause of such residual coarctation. Tubular hypoplasia of the aortic arch did not play a significant role because, by the time of reoperation, the arch had grown to normal dimension in each patient who had arch hypoplasia in infancy.

Causes of recurrent coarctation: The remaining patients may be described as having recurrent coarctation. Their recurrent gradient was first detected an average of 2.8 years after initial repair. Possible mechanisms involved in the pathogenesis of recurrent coarctation include (1) inadequate growth of the anastomosis, possibly related to the use of continuous sutures $^{14 ;}$ (2) active fibrosis and narrowing of the anastomosis site; (3) thrombosis of the suture line; and (4) retention of abnormal, possibly ductal, tissue with the potential for proliferation and luminal narrowing. ${ }^{13}$ Moss et al. ${ }^{18}$ demonstrated angiographically that by age 3 years the descending aorta has grown to 55 percent of 
TABLE IV

Graded Treadmill Exercise Testing (Bruce Protocol) in Five Patients After Reoperation for Coarctation

\begin{tabular}{|c|c|c|c|c|c|}
\hline \multirow[b]{2}{*}{ Case } & \multirow{2}{*}{$\begin{array}{c}\text { Heart } \\
\text { Rate } \\
\text { (beats/min) }\end{array}$} & \multicolumn{3}{|c|}{ Pressures $(\mathrm{mm} \mathrm{Hg})$} & \multirow[b]{2}{*}{ Reoperation } \\
\hline & & Right Arm & Right Leg & Gradient & \\
\hline \multicolumn{6}{|l|}{2} \\
\hline $\begin{array}{l}\text { Rest } \\
\text { Exercise }\end{array}$ & $\begin{array}{r}87 \\
184\end{array}$ & $\begin{array}{l}155 / 82 \\
208 / 90\end{array}$ & $\begin{array}{l}155 / 80 \\
176 / 60\end{array}$ & $\begin{array}{r}0 \\
32\end{array}$ & Patch aortoplasty \\
\hline $\begin{array}{l}\text { Rest } \\
\text { Exercise }\end{array}$ & $\begin{array}{r}94 \\
170\end{array}$ & $\begin{array}{l}106 / 60 \\
140 / 90\end{array}$ & $\begin{array}{c}91 /- \\
110 /\end{array}$ & $\begin{array}{l}15 \\
30\end{array}$ & Patch aortoplasty \\
\hline $\begin{array}{l}6 \\
\text { Rest } \\
\text { Exercise }\end{array}$ & $\begin{array}{r}60 \\
183\end{array}$ & $\begin{array}{l}138 / 64 \\
300 / 60\end{array}$ & $\begin{array}{l}138 /- \\
166 /-\end{array}$ & $\begin{array}{r}0 \\
134\end{array}$ & $\begin{array}{l}\text { Left subclavian- } \\
\text { aorta bypass graft }\end{array}$ \\
\hline 7 & & & & & \\
\hline 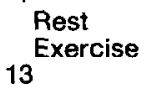 & $\begin{array}{r}76 \\
200\end{array}$ & $\begin{array}{l}114 / 52 \\
234 / 60\end{array}$ & $\begin{array}{l}100 / 75 \\
154 / 70\end{array}$ & $\begin{array}{l}14 \\
80\end{array}$ & End to end \\
\hline $\begin{array}{l}\text { Rest } \\
\text { Exercise }\end{array}$ & $\begin{array}{r}90 \\
192\end{array}$ & $\begin{array}{l}150 / 95 \\
204 / 100\end{array}$ & $\begin{array}{l}135 /- \\
130 /-\end{array}$ & $\begin{array}{l}15 \\
74\end{array}$ & Interposition graft \\
\hline
\end{tabular}

Values are those recorded at rest and immediately after peak exercise.

its adult diameter. Because previous work by Clatworthy et al. ${ }^{19}$ had shown that significant obstruction occurs only when the aortic diameter is reduced by 50 percent or more, it was concluded that the risk of recurrent coarctation is small with repair after the age 3 years even if no further growth at the repair site were to occur.

Our data are consistent with the hypothesis that recurrent coarctation results from inadequate anastomotic growth because the incidence of reoperation is significantly increased for patients younger than age 3 years at initial operation. Were active narrowing a major factor in recurrent coarctation one would expect a higher recurrence rate in patients aged 3 years or older at initial repair. Narrowing of the anastomosis may have occurred in some patients, specifically those with a marked or rapidly developing stenosis at the site of initial repair. Dense fibrous adhesions in the area of the coarctation were observed at reoperation in most patients and in some may have played a role in narrowing or limiting the growth of the anastomosis. Inhibition of anastomotic growth by continuous sutures did not occur because in the large majority interrupted suture technique was used at initial repair. Recent studies ${ }^{20-22}$ indicated that the use of subclavian flap angioplasty may decrease the incidence of recurrent coarctation by permitting ongoing growth at the repair site. During the past 4 years we have abandoned end to end anastomosis in favor of this technique for repair of coarctation in infancy.

Safety and results of reoperation: Our study contrasts with the few previous reports on reoperation for coarctation that cite operative mortality rates of $7.3,15$ $15^{14}$ and as high as 33 percent. ${ }^{16}$ Uncontrollable hemorrhage from a friable aorta, often surrounded by dense adhesions, is the most frequently mentioned cause of intraoperative death. Concern over the apparent high frequency of serious complications encountered during reoperation prompted Weldon ${ }^{23}$ and Edie $^{24}$ and their co-workers to recommend graft insertion as the surgical technique of choice. However, our data indicate that reoperation can be a safe and effective procedure for the patient whose initial repair proves unsuccessful. In this series operative morbidity was minimal and there was only one operative death (4.8 percent mortality rate). Follow-up data indicate that reoperation has significantly relieved symptoms, upper limb hypertension and coarctation pressure gradient at rest.

In the only other long-term follow-up study of patients undergoing reoperation for coarctation, Castaneda and Norwood ${ }^{15}$ reported a 30 percent incidence rate of a residual pressure gradient at rest of $40 \mathrm{~mm} \mathrm{Hg}$ or more. These results were attributed to the use of end to end anastomosis, a technique they subsequently abandoned. There was no discussion of symptoms or upper limb hypertension after reoperation. In our study we observed a 35 percent incidence rate of pressure gradient at rest after reoperation but, in contrast, all gradients were $20 \mathrm{~mm} \mathrm{Hg}$ (mean $4.6 \pm 1.5 \mathrm{~mm} \mathrm{Hg}$ ) or less. The majority appear to represent true residual coarctations because they were recognized in the immediate postoperative period, and none has progressed with time.

Role of exercise testing: Several studies have documented an increase in coarctation pressure gradient with dynamic exercise after initial repair. ${ }^{25-27}$ Our data (Table IV) indicate that this is also true after reoperation. 'The coarctation gradient increased with exercise in all five patients tested, a marked increase occurring in three. One patient with no pressure gradient at rest had a severe (134 $\mathrm{mm} \mathrm{Hg}$ ) gradient with exercise. Significant upper limb hypertension developed in four patients during exercise and increased to dangerous levels ${ }^{28}$ in two patients. These results clearly indicate the importance of exercise testing in the evaluation of patients after reoperation for coarctation. Although gratifying normalization of blood pressure and coarctation gradient is observed at rest, this finding may not occur during strenuous exercise.

Surgical implications: On the basis of this experience we believe that reoperation is indicated for patients with residual or recurrent coarctation who are hyper- 
tensive or symptomatic and whose coarctation pressure gradient at rest is $30 \mathrm{~mm} \mathrm{Hg}$ or more. Patch aortoplasty appears to be the most satisfactory technique for reoperation. It can be performed safely, because dissection around the aorta is minimized, and follow-up data indicate that significant clinical and hemodynamic benefit has been achieved. Similarly, end to end anastomosis was performed successfully in three patients. However, two of three survivors of graft interposition have a residual coarctation gradient at rest and remain hyper- tensive. The only operative death occurred in a patient who underwent graft interposition. Finally, of the two patients who had a left subclavian to descending aorta bypass graft one has exhibited severe upper limb hypertension and an impressive coarctation gradient during exercise. Although the numbers arc small these data suggest that, despite previous recommendations, ${ }^{23,24}$ patch aortoplasty rather than graft insertion may be the surgical technique of choice for reoperation.

\section{References}

1. Maron BJ, Humphries JO, Rowe RD, Mellits ED. Prognosis of surgically corrected coarctation of the aorta. A 20-year postoperative appraisal. Circulation 1973;47:119-26.

2. Simon AB, Zloto AE. Coarctation of the aorta. Longitudinal assessment of operated patients. Circulation 1974;50:456-63.

3. Hubbell MM, O'Brien RG, Krouvetz LJ, Mauck HP, Tompkins DG. Status of patients 5 or more years after correction of coarctation of the aorta over age 1 year. Circulation 1979;60:74-9.

4. Pennington DG, Liberthson RR, Jacobs $M$, Scully $H$, Goldblatt A, Daggett WM. Critical review of experience with surgical repair of coarctation of the aorta. J Thorac Cardiovasc Surg 1979;77: 217-29.

5. Patel R, Singh SP, Abrams L, Roberts KD. Coarctation of aorta with special reference to infants. Long-term results of operation in 126 cases. Br Heart J 1977;39:1246-53.

6. Herrmann VM, Laks H, Fagan L, Terschluse D, Willman VL. Repair of aortic coarctation in the first year of life. Ann Thorac Surg 1978;25:57-63

7. Bjork VO, Bergdahi L, Jonasson R. Coarctation of the aorta. The world's longest follow-up. Adv Cardiol 1978;22:205-15.

8. Nanton MA, Olley PM. Residual hypertension after coarctation in children. Am J Cardiol 1976;37:769-72.

9. Connors JP, Hartmann AF, Weldon CS. Considerations in the surgical management of infantile coarctation of aorta. Am J Cardiol 1975;36:489-92.

10. Hartmann AF, Goldring D, Hernandez A, et al. Recurrent coarc tation of the aorta after successful repair in infancy. Am J Cardiol 1970;25:405-10.

11. Eshaghpour E, Olley PM. Recoarctation of the aorta following coarctectomy in the first year of life: a follow-up study. J Pediatr 1972;80:809-14.

12. Parsons CG, Astley R. Recurrence of aortic coarctation after operation in childhood. Br Med J 1966;1:573-77.

13. Khoury GH, Hawes CR. Recurrent coarctation of the aorta in infancy and childhood. J Pediatr 1968;72:801-6.

14. Ibarra-Perez C, Castaneda AR, Varco RL, Lillehel CW. Recoarctation of the aorta. Nineteen year clinical experience. Am J Cardiol 1969;23:778-84.

15. Castaneda AR, Norwood WI. Residual coarctation of the aorta: surgical experience. In: Tucker BL, Lindesmith GC, eds. Congenital Heart Disease. New York: Grune \& Stratton, 1979:167-78.
16. Cerilli $\mathrm{J}$, Lauridsen P. Reoperation for coarctation of the aorta. Acta Chir Scand 1965;129:391-4.

17. National Heart, Lung, and Blood Institute's Task Force on Blood Pressure Control in Children: report of the Task Force on Blood Pressure Control in Children. Pediatrics 1977;59:797-820.

18. Moss AJ, Adams FH, O'Loughlin BJ, Dixon WJ. The growth of the normal aorta and of the anastomotic site in infants following surgical resection of coarctation of the aorta. Circulation 1959;19: $338-49$.

19. Clatworthy HW, Sako Y, Chisholm TC, Clumer C, Varco RL. Thoracic aortic coarctation: its experimental production in dogs, with special reference to technical methods capable of inducing significant intraluminal stenosis. Surgery 1950;28:245-72.

20. Plerce WS, Waldhausen JA, Berman W Jr, Whitman V. Late results of the subclavian flap procedure in infants with coarctation of the thoracic aorta (abstr). Circulation 1977;56:Suppl III:III103.

21. Thibault WN, Sperling DR, Gazzaniga MD. Subclavian artery patch angioplasty. Arch Surg 1975;110:1095-8.

22. Hamilton DI, DiEusanlo G, Sandrasagra FA, Donnelly RJ. Early and late results of aortoplasty with a left subclavian flap for coarctation of the aorta in infancy. $J$ Thorac Cardiovasc Surg 1978;75:699-704

23. Weldon CS, Hartmann AF, Steinhoft NG, Morrissey JD. A simple, safe, and rapid technique for the management of recurrent coarctation of the aorta. Ann Thorac Surg 1973;15:510-9.

24. Edle RN, Jananl J, Attai LA, Malm Jr, Roblnson G. Bypass grafts for recurrent or complex coarctations of the aorta. Ann Thorac Surg $1975 ; 20: 558-64$.

25. Ikkos D, Wallgren G, Zettergvist P. Coarctation of the aorta: a postoperative functional study. Acta Paediatr 1959;48:353-60.

26. Freed MD, Rocchini A, Rosenthal A, Nadas AS, Castaneda AR. Exercise-induced hypertension after surgical repair of coarctation of the aorta. Am J Cardiol 1979;43:253-8.

27. Connor TM. Evaluation of persistent coarctation of aorta after surgery with blood pressure measurement and exercise testing. Am J Cardiol 1979;43:74-8.

28. Nudel DB, Goolman N, Brunson SC, Stenzler A, Shenker IR, Gauthier BG. Exercise performance of hypertensive adolescents. Pediatrics 1980;65:1073-8. 